\title{
DEVELOPMENT OF STUDENTS' WORKSHEET WITH MIND MAPPING STRATEGY TO IMPROVE CREATIVE THINKING SKILLS ON STOICIOMETRY
}

\author{
Hikma Wardani ${ }^{* 1}$, Mitarlis ${ }^{2 *}$ \\ ${ }^{1,2}$ Jurusan Kimia FMIPA Universitas Negeri Surabaya \\ *Corresponding author:mitarlis@unesa.ac.id
}

\begin{abstract}
The purpose of this study is to describe the feasibility of the Students' Worksheet with the mind mapping strategy to improve the students' creative thinking skills on stoichiometry material. There are tree aspects which were observed in the students' worksheets to measure the feasibility, those are content, presentation, and language. This study was conducted based on 4-D development model which has been modified into 3-D (define, design, and develop).Furthermore, the results showed that from the three aspects of students' worksheet which were content, presentation and language were categorized to be very feasible with the percentage $91.88 \% ; 93.55 \% ; 86.67 \%$. Based on the results it can be concluded that the students' worksheet with a mind mapping strategy was feasible and able to improve the students' creative thinking skills and learning outcomes on stoichiometry material.
\end{abstract}

Keywords: Creative thinking, mind mapping, stoichiometry.

\section{PENDAHULUAN}

Pendidikan adalah salah satu upaya individu untuk menumbuhkan potensi yang dimiliki melalui proses pembelajaran, agar dapat mencapai tujuan pendidikan yakni kepribadian individu yang lebih baik. Sarana untuk mencapai tujuan pendidikan tersebut yaitu salah satunya dengan meningkatkan kualitas melalui pengembangan kurikulum. Pemerintah memprogram kurikulum 2013 untuk mewujudkan tujuan pendidikan dengan karakteristik mengembangkan keterampilan sikap, berpikir, sosial, akademik, dan vokasional(1). Pembelajaran IPA termasuk kimia berusaha untuk meningkatkan pemahaman serta kecerdasan peserta didik melalui pembentukan sikap, pengetahuan, dan keterampilan seperti keterampilan bekerja sama, keterampilan berkomunikasi, keterampilan berfikir kritis, dan lain sebagainya.

Kimia yakni rumpun IPA yang mempelajari mengenai struktur, komposisi, sifat, dan perubahan materi serta energetika zat yang melibatkan keterampilan dan penalaran. Oleh karena itu, pembelajaran kimia dan penilaian hasil belajarharus memperhatikan komponen kompetensi sikap spiritual, sosial, pengetahuan, dan keterampilan. Berdasarkan hal tersebut, diharapkan melaluikimia peserta didik mampumemiliki beberapa sikap sepertiberpikir logis, analitis, kreatif, rasa ingin tahu, jujur, disiplin, tekun, ulet, tanggung jawab, dan peduli (2).

Fungsi bahan ajar sangat berpengaruhsaat proses pembelajaran karena dapat meningkatkan minat dan kreatifitas belajar peserta didik. LKPD merupakan salah satu bahan ajar yang dapat mendukung keterampilan berpikir kreatif. Melalui LKPD yang kreatif dan inovatif proses pembelajaran menjadi menyenangkan dan bermakna, sehingga mudah untuk memahami materi. LKPD tersebut menyajikan beberapa tugas yang dapat disusun dan diubah oleh guru berdasarkan dengan objek yang ingin dicapai serta suasana di lapangan (3).

Stoikiometri memiliki karakteristik mempelajari tentang keterampilan, operasi matematika dan pemecahan soal secara bertahap didukung dengan latihan yang terus menerus. Hasil angket yang dilakukan di SMA Negeri 3 Kota Mojokerto, peserta didik sebanyak $75,75 \%$ menyatakan mengalami kesulitan pada materi stoikiometri. Peserta didik menuliskan bahwa materi stoikiometri banyak perhitungan dan hafalan yang sulit dipahami serta sumber belajar yang kurang 
memadai. Peserta didik merasa kesulitan mempelajari stoikiometri.

Startegi mind mappingyakni cara mencatat kreatif dan efektif untuk menyederhanakan kita dalam mengingat banyak informasi. Mind mappingyakni pemetaan pikiran seseorang yang dituangkan dalam bentuk diagram sederhana dan dapat menggambarkarkan keseluruhan materi(4). Imajinasi yang muncul akibat dari kebebasan berekspresi melalui strategi mind mappingakan merangsang keterampilan berpikir kreatif peserta didik.

Keterampilan berpikir kreatif adalah kemampuan untuk menyelesaikan suatu permasalahan dengan menggunakan berbagai cara yang berbeda-beda. Berpikir kreatif yakni kemampuan peserta didik dalam menguasaipersoalan dan menemukan peyelesaian dengan strategi yang bervariasi. Karakteristik keterampilan berpikir kreatif secara operasional dapat dirumuskan sebagai kemampuan yang mencerminlkan kelancaran (fluency), keluwesan (flexibility), dan kebaruan (originality) dalam berpikir(5).

Penelitian yang dilakukan oleh Ainurrohmah (2019) menunjukkan bahwa hasil LKPD dengan strategi mind mappingdinyatakan layak ditinjau dari kevalidan, kepraktisan dan keefektifan. Hasil yang diperoleh rata-rata $>61 \%$, sehingga dapat dinyatakan layak (6).

Penelitian yang dilakukan oleh Qomariyah (2017) menunjukkan bahwa hasil aktivitas peserta didik yang dominan adalah memperhatikan penjelasan guru, mengerjakan soal uji kompetensi pada LKS, berdiskusi dengan pasangannya, membuat mind map serta mempresentasikan hasil. Keterampilan berpikir kreatif peserta didik mengalami peningkatan dengan berbagai kategori, sebesar $21,73 \%$ dengan kategori rendah, 47,82\% kategori sedang dan 30,43\% termasuk kategori tinggi(7).

Teori pemrosesan informasi mengatakan bahwa materi yang diterima oleh peserta didik saat kegiatan pembelajaran akan diproses dan diolah dalam memori melalui tiga tahapan yaitu sensory memory, short-term memory, dan long-term memory. Ketika peserta didik mendapatkan informasi baik dari orang lain maupun saat membaca, maka dibutuhkan cara untuk mengorganisasi informasi tersebut agar dapat masuk ke dalam memori jangka panjang
(8). Kemampuan mengorganisasi informasi bergantung pada usia dan gaya belajar. Upaya untuk membantu dalam mengorganisasi informasi maka dibutuhkan suatu strategi, salah satunya yaitu mind mapping.

Usia peserta didik SMA kelas $\mathrm{X}$ ratarata sekitar 15-16th, menurut teori perkembangan kognitif Piaget berada pada tahap formal operation. Pada usia tersebut peserta didik sudah mampu berpikir abstrak. Jika dihadapkan suatu masalah, peserta didik mampu menentukan hal yang paling mungkin terjadi berdasarkan kemamuan berpikir analitis, kreatif, dan logis (9).

Berdasarkan hasil studi lapangan, proses pembelajaran di SMA Negeri 3 Kota Mojokertomemakai buku paket danLKPD sebagai sumber belajar. Buku paket yang digunakan yakni sarana sekolah dari pemerintah, namun yang diberikan jumlahnya terbatas, sehingga peserta didik menggunakan sumber lain yaitu LKPD. LKPD yang digunakan tidak dikembangkan oleh gurunya sendiri, melainkan dari salah satu penerbit yang dijual di pasaran. LKPD tersebut berisi materi secara singkat dan soal-soal yang harus dikerjakan, namun tidak sesuai dengan kondisi peserta didik, sehingga masih kurang efektif keaktifan peserta didik saat pembelajaran dan keterampilan berpikir kreatifnya.

Salah satu petunjuk dalam membuat mind map yaitu menggunakan warna, karena akan terlihat menjadi lebih hidup dan menarik. Berdasarkan hasil angket pra penelitian sebanyak $84,85 \%$ menuliskan ringkasan materi yang dibuat berwarna-warni dan penuh gambar dapat membuat materi mudah dipahami, serta sebanyak $87,88 \%$ peserta didik tidak pernah menerapkan strategi mind mapping dalam pembelajaran. Berdasarkan fakta di lapangan, LKPD yang digunakan tidak dilengkapi dengan pemetaan materi yang jelas dan kurang menarik untuk dipelajari, sehingga dibutuhkan LKPD yang dapat membuat peserta didik tertarik untuk belajar dan lebih memahami materi.

Berdasarkan fakta tersebut, peneliti mengembangkan LKPD dengan strategi mind mapping agar peserta didik diharapkan tidak mengalami kerumitan dalam mempelajari materi stoikiometri dan dapat meningkatkan keterampilan berpikir kretif. Oleh karena itu, perlu dilakukan penelitian dengan judul "Pengembangan Lembar Kerja Peserta Didik 
(LKPD) dengan Strategi Mind Mapping untuk Meningkatkan Keterampilan Berpikir Kreatif Peserta Didik pada Materi Stoikiometri”

\section{METODE}

Modelpengembangan yang digunakan dalam penelitian ini adalah 4-D oleh Thiagarajan, Semmel, dan Semmel. Model 4D ini meliputi empat tahap penelitian meliputi define, design, develop, dan disseminate. Pada penelitian ini hanya dilakukan sampai tahap develop. Sasaran penelitian yakni pengembangan perangkat pembelajaran berupa Lembar Kerja Peserta Didik (LKPD) dengan strategi mind mappinguntuk meningkatkan keterampilan berpikir kreatif peserta didik pada materi stoikiometri. Data yang akan digunakan bersumber dari ahli materi yaitu dosen kimia, kemudian guru kimia dan peserta didik kelas X.

Ahli materi memberikan saran dan pendapat dengan mengisi lembar telaah agar LKPD yang dikembangkan menjadi lebih baik lagi. Kemudian LKPD dengan strategi mind mapping diuji kelayakannya dengan validitas yang ditinjau dari isi, penyajian dan kebahasaan kemudian diimplementasikan di lapangan untuk mengetahui aktivitas,respon, peningkatan keterampilan berpikir kreatif dan hasil belajar pada materi stoikiometri. Uji coba terbatas diberikan kepada 12 peserta didik dengan 5 kali pertemuan dan dilaksanakan menggunakan metode eksperimen one group pre tespos test design. LKPD yang dikembangkan selain berstrategi mind mapping, juga bersintaks Think Pair Share (TPS).

Keterangan:

$$
\mathrm{O}_{1} \quad \mathrm{X} \quad \mathrm{O}_{2}
$$

$\mathrm{O} 1=$ pretest keterampilan berpikir kreatif dan pengetahuan

$\mathrm{O} 2$ = pos test $\mathrm{keterampilan}$ berpikir kreatif dan pengetahuan

$\mathrm{X}=$ pembelajaran stoikiometri menggunakan

LKPD dengan strategi mind

mappingbersintaks model pembelajaran

koopertaif tipe think pair share.

Sebelum dilakukan implementasi, 3 validator yakni 2 ahli materi dan 1 guru kimia memberikan penilaian pada lembar validasi untuk mengetahui kelayakan LKPD. Berdasarkan Depdiknas kelayakan mencakup
3 aspek diantaranya yaitu isi, penyajian dan kebahasaan, kemudian dihitung persentasenya.

Hasil persentase yang diperoleh diinterpretasikan ke dalam kriteria yang disajikan pada Tabel 1.

Tabel 1. Kriteria Persentase

\begin{tabular}{cc}
\hline Persentase (\%) & Kriteria \\
\hline $0-20$ & Tidak Layak \\
$21-40$ & Kurang Layak \\
$41-60$ & Cukup Layak \\
$61-80$ & Baik/Layak \\
$81-100$ & Sangat baik/ Sangat layak \\
\hline
\end{tabular}

LKPD dengan strategi mind mappingdinyatakan layak apabila persentase nilai yang diperoleh $\geq 61 \%$. Tahap selanjutnya yaitu dilakukan uji coba terbatas kepada 12 peserta didik X MIPA 2 SMA Negeri 3 Mojokerto. Data kelayakan diperoleh dari uji coba terbatas yaitu berupa respon peserta didik, observasi aktivitas selama pembelajaran, peningkatan keterampilan berpikir kreatif serta hasil belajar pada materi stoikiometri.

Analisis data observasi aktivitas peserta didik dan respon dilakukan dengan deskriptif kuantitatif yaitu menghitung persentase kegiatan sesuai dengan kategori yang disediakan. Persentase data hasil respon peserta didik diperoleh berdasarkan skala Guttman yakni jika respon positif maka mendapatkan poin 1 , dan jika respon negatif maka mendapatkan poin 0 .

Kemudian hasil persentase yang diperoleh diinterpretasikan ke dalam kriteria yang disajikan pada Tabel 1. Berdasarkan hasil analisis lembar observasi dan respon peserta didik dapat dikatakan bahwa LKPD layak apabila persentase yang diperoleh $\geq 61 \%$.

Peserta didik diberikan soal pre tesdan pos testberupa essay untuk mengetahui pengaruhpenggunaan LKPD dengan strategi mind mapping. Kemudian untuk mengetahui peningkatan keterampilan berpikir kreatif, peserta didik diberikan soal berisi bacaan lalu diminta membuatmind map. Analisis hasil belajar dan keterampilan berpikir kreatif pada materi stoikiometri dihitung menggunakan rumus:

Poin total $=\frac{\text { jumlah poin yang diperoleh }}{\text { poin maksimum }} \times 100$ 
Berdasarkan rumus tersebut akan didapatkan tiap-tiappoinpre tesdan pos test. Kemudian hasil tersebut dihitung nilai normalitasnnya untuk menentukan bahwa data yang didapat telah berdistribusi normal.Langkah selanjutnya yaitu menghitung besarnya peningkatan keterampilan berpikir kreatif dan hasil belajar selama penggunaan LKPD dengan rumus $N$-Gain seperti di bawah ini:

$$
\text { Normal gain }=\frac{\text { nilai posttest }- \text { nilai pretest }}{\text { nilai ideal }- \text { nilai pretest }}
$$

Berdasarkan hasil perhitungan nilai $\langle\mathrm{g}>$ akan didapatkan hasil dari sebelum dan sesudah penggunaan LKPD dengan strategi mind mappinglalu dikategorikan menggunakan kriteria poin pada Tabel 2.

\section{Tabel 2. Klasifikasi $N$-Gain}

\begin{tabular}{cc}
\hline Rentang Persentase & Kriteria \\
\hline $\mathrm{g}<0,3$ & Rendah \\
$0,3<\mathrm{g}<0,7$ & Sedang \\
$\mathrm{g} \geq 0,7$ & Tinggi \\
\hline
\end{tabular}

LKPD dinyayatakan layak apabila hasil peningkatan hasil belajar dan keterampilan berpikir kreatif mencapai kriteria minimal sedang atau $\geq 0,3$.

\section{HASILDAN PEMBAHASAN}

\section{Kelayakan LKPD}

Kelayakan LKPDberdasarkan depdiknas mencakup tiga aspek yaitu isi, penyajian dan kebahasaan. Dosen kimia dan guru menjadi validator untuk menguji kelayakan LKPD. Data hasil penilaian tiap-tiap aspek mencapai persentase yang disajikan pada Tabel 3 .

Tabel 3. Data Hasil Kelayakan

\begin{tabular}{ccl}
\hline $\begin{array}{c}\text { Aspek } \\
\text { Kelayakan }\end{array}$ & Persentase & \multicolumn{1}{c}{ Kategori } \\
\hline Isi & 91,88 & Sangat Layak \\
Penyajian & 93,55 & Sangat Layak \\
Kebahasaan & 86,67 & Sangat Layak \\
Rata-rata & $\mathbf{9 0 , 7 0}$ & Sangat Layak \\
\hline
\end{tabular}

Berdasarkan Tabel 3, hasil persentase menunjukkan bahwa LKPD yang dikembangkan telah memennuhi kriteria kelayakan dan siap untuk diuji cobakan terhadap peserta didik. Hal itu dibuktikan dengan perolehan persentase sebesar $\geq 61 \%$ dengan kategori sangat layak.

\section{Uji Coba Terbatas}

Uji coba terbatas yakni tahap pengujian rancangan produk terhadap sasaran subjek yaitu peserta didik. Tahap ini dilakukan untuk implementasi LKPD di lapangan. Data yang didapat dari tahap uji coba terbatas adalah observasi aktivitas peserta didik, respon, hasil pre tes dan pos testpada tes keterampilan berpikir kreatif yang berupa mind map serta hasil belajar peserta didik pada materi stoikiometri.

Data observasi aktivitas peserta didik digunakan untuk melihat gambaran kegiatan yang dilakukan selama implementasi. Berikut adalah data hasil rekapitulasi aktivitas peserta didik dari pertemuan pertama hingga terakhir disajikan pada Tabel 4.

\section{Tabel 4.Hasil Rekapitulasi Aktivitas Peserta Didik}

\begin{tabular}{ccc}
\hline Pertemuan & Persentase Hasil Observasi \\
& \multicolumn{2}{c}{$(\mathbf{\%})$} \\
\cline { 2 - 3 } & Relevan & Tidak Relevan \\
\hline Pert. 1 & 96,43 & 3,57 \\
Pert. 2 & 98,58 & 1,42 \\
Pert. 3 & 97,86 & 2,14 \\
Persentase & $\mathbf{9 7 , 6 2}$ & $\mathbf{2 , 3 8}$ \\
Rata-rata & & \\
\hline
\end{tabular}

Berdasarkan data tersebut, aktivitas yang relevan mencapai persentase $\geq 61 \%$, sehingga dapat dikatakan LKPD layak bersarkan data observasi aktivitas peserta didik. Pada Gambar 1, disajikan aktivitas peserta didik berupa hasil mind map pada materi hukum dasar ilmu kimia.

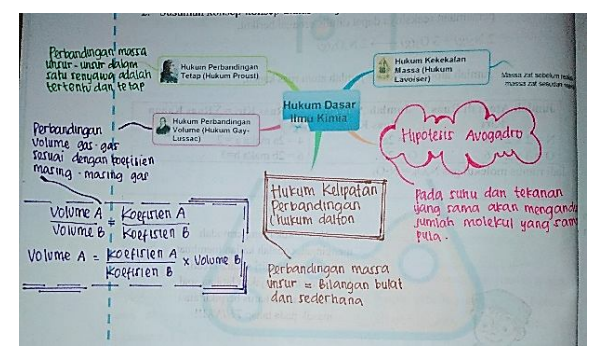

\section{Gambar 1.Aktivitas Peserta Didik Membuat Mind Map}

Pada Gambar 2, aktivitas peserta didik yaitu mengerjakan latihan soal pada materi 
kadar zat dalam campuran tentang molaritas dan molalitas.

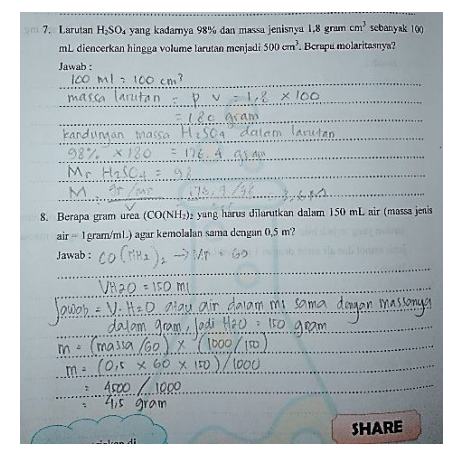

\section{Gambar 2.Aktivitas Peserta Didik Mengerjakan Latihan Soal}

Peserta didik sangat antusias terhadap LKPD dengan strategi mind mapping, karena dengan membuat mind map materi yang diberikan menjadi mudah dipahami. Selain itu juga, pembelajaran ini menggunakan model Think Pair Share, sehingga sesama teman bisa saling berdisukusi.

Hasil data pre tes dan pos test mind map digunakan untuk mendapati peningkatan keterampilan berpikir kreatif setelah menggunakan LKPD dengan strategi mind mapping.Gambar 3 dan 4 yaknihasil karyamind map peserta didik dengan tingkat keterampilan berpikir kreatifnya.

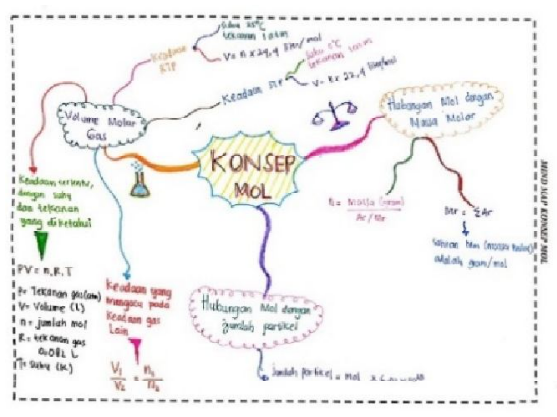

\section{Gambar 3. Hasil Pos test Mind mapping Kategori Sangat Kreatif}

Gambar 3 termasuk kategori sangat kreatif. Poinpada aspek kelancaran dapat terpenuhi karena peserta didik menyebutkan kata kunci (tema, sub tema, cabang dan sub cabang) lebih dari sama dengan 5. Kemudian cabang sesuai dengan atuan pembuatan mind map yaitu dengan menghubungkan ke tema dan garis melengkung. Selanjutnya yaitu letak gagasan utama (tema) berada di tengah. Aspek keluwesan dapat dipenuhi karena peserta didik membuat bentuk cabang tebal dan panjang, kemudian menggunakan banyak warna, lalu diberi gambar atau simbol. Penggunaan warna dan gambar dapat menarik peserta didik dan menambah energi pada pemikiran kreatif dan menyenangkan. Penggunaan yang dimaksud menurut aturan mind map seharusnya warna pada sub tema dan cabang lalu sub cabang harus sama, sehingga alur warna yang tercipta sama. Jadi perbedaan warna yang dimaksud yaitu antar sub tema. Sub cabang yang berasal dari sub tema yang sama tidak boleh berbeda, agar otak lebih mudah menyimpan informasi. Aspek selanjutnya yaitu orisinalitas. Peneliti mengamati desain yang dibuat yakni sesuatu yang baru dan berbeda antar peserta didik. Jika ada desain yang sama maka aspek orisinalitas belum terpenuhi secara sempurna. Penggunaan banyak warna akan membuat produk semakin bervariasi dan setiap peserta didik memiliki pemikiran yang berbeda-beda. Semua produk yang dihasilkan saat pos testyakni hasil asli dari kreativitas mereka termasuk bentuk simbol, warna, dan tata letak, sehingga tiap produk memiliki keunikan tersendiri.

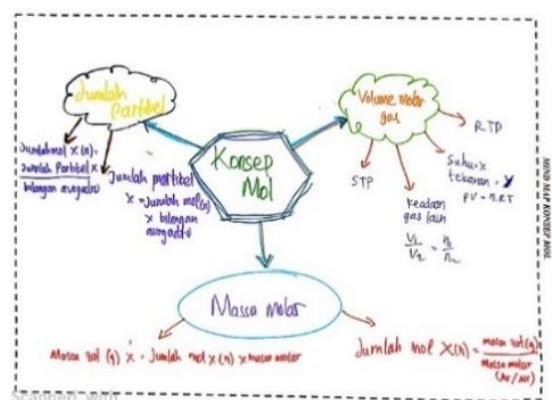

\section{Gambar 4. Hasil Pos test Mind mapping} Kategori Kreatif

Gambar 4 termasuk kategori kreatif. Ada dua aspek yang belum terpenuhi sempurna, namun masih dalam kategori kreatif. Aspek tersebut adalah kelancaran karena peserta didik tidak membuat cabang dengan garis melengkung. Aspek selanjutnya yang tidak terpenuhi dengan sempurna yaitu pada keluwesan. Peserta didik menggunakan warna yang sama antar cabang, sehingga mind map kurang bervariasi.Hasil tersebut yakni nilai terendah di antara peserta didik yang lain. Meskipun termasuk nilai terendah, peserta didik tersebut mempertahankan keorisinilan mind map.

Tabel 5 menjelaskan hasil rerata pre tes dan pos testmind mapping serta $N$-Gain yang diperoleh pada materi stoikiometri. 
Tabel 5. Data Hasil Pre tes dan Post test Mind mapping

\begin{tabular}{ccc} 
Perlakuan & $\begin{array}{c}\text { Hasil } \\
\text { Rata-rata }\end{array}$ & $\begin{array}{c}\text { Tingkat Berpikir } \\
\text { Kreatif }\end{array}$ \\
\hline Pretest & $51,67 \%$ & Cukup Kreatif \\
Posttest & $86,67 \%$ & Sangat Kreatif \\
$N$-Gain & 0,74 & Tinggi \\
\hline
\end{tabular}

Berdasarkan data hasil pada Tabel 5, peserta didik dinyatakan mengalami peningkatan keterampilan berpikir kreatif melalui mind map. Jadi, LKPD dengan strategi mind mapping dapat dikatakan layak.

Hasil belajar peserta didik didapatkan dari soal pre tes dan pos test yang berupa 7 soal essay tentang materi stoikometri. Tiaptiap nomor soal mengandung sub materi yang diajarkan dan sesuai dengan isi LKPD. Berikut adalah hasil belajar peserta didik pada materi stoikiometri yang disajikan pada Tabel 6 .

\section{Tabel 6. Data Hasil Pre tes dan Pos test} Stoikiometri

\begin{tabular}{ccc}
\hline Perlakuan & $\begin{array}{c}\text { Hasil } \\
\text { Rata-rata }\end{array}$ & $\begin{array}{c}\text { Kategori Hasil } \\
\text { Belajar }\end{array}$ \\
\hline Pretest & 38,89 & Kurang \\
Posttest & 84,49 & Sangat Baik \\
$N$-Gain & 0,75 & Tinggi \\
\hline
\end{tabular}

Berdasarkan data pada Tabel 6, peserta didik mengalami hasil belajar yang cukup signifikan. Melalui pembelajaran menggunakan bahan ajar LKPD dengan strategi mind mapping, peserta didik mampu mencapai hasil sangat baik pada materi stoikiometri dan dapat dikatakan layak digunakan.Kelayakan LKPD berdasarkan hasil respon peserta didik ditampilkan pada Tabel 7.

Tabel 7. Hasil Respon Peserta Didik

\begin{tabular}{ccc}
\hline Kriteria & Persentase (\%) & Kategori \\
\hline Isi & 89,59 & Sangat Layak \\
Kebahasaan & 83,33 & Sangat Layak \\
Penyajian & 91,67 & Sangat Layak \\
Rata-rata & $\mathbf{8 8 , 0 2}$ & Sangat Layak \\
\hline
\end{tabular}

Berdasarkan Tabel 7 dapat dijelaskan bahwa setiap aspek memenuhi kategori sangat layak dengan mencapai persentase rata-rata sebesar $88,02 \%$. Hal ini menyuratkan bahwa LKPD yang diberikan kepada peserta didik mendapatkan respon positif, sehingga pembelajaran menjadi bermakna dan meningkatkan keterampilan berpikir kreatif serta hasil belajar pada materi stoikiometri.

\section{PENUTUP \\ Simpulan}

Berdasarkan kesesuaian antara hasil penelitian dan rumusan masalah serta analisis datadapat ditarik kesimpulan bahwa LKPD tersebuttelah melengkapi syarat kelayakan ditinjau dari isi, penyajian dan kebahaasaan. Kelayakan LKPD ditinjau dari tiga aspek tersebut mencapai persentase rata-rata sebesar 90,70\% dengan kategori sangat layak. Implementasi LKPD di lapangan ditinjau dari aktivitas peserta didik sebesar 97,62\%, keterampilan berpikir kreatif mengalami peningkatan sebesar 0,74, hasil belajar peningkatan sebesar 0,75 dan respon positif peserta didik sebesar $88,02 \%$.

\section{Saran}

Berdasarkan uji kelayakan pada penelitian pengembangan ini, dapat dikemukakan saran untuk dapat menerapkan LKPD dengan strategi mind mappingmemerlukan alokasi waktu lebih, sehingga perlu direncanakan dengan seksama. Alat tulis berwarna untuk membuat mind map perlu disediakan lebihbanyak agar peserta didik lebih termotivasi dan belajar menjadi lebih bermakna.

\section{DAFTAR PUSTAKA}

[1]Permendikbud. 2013. Peraturan Menteri Pendidikan dan Kebudayaan Republik Indonesia Nomor 69 Tahun 2013 Tentang Kerangka Dasar dan Struktur Kurikulum Sekolah Menengah Atas/Madrasah Aliyah. Jakarta: Badan Standar Nasional Pendidikan.

[2]Permendikbud. 2016. Peraturan Menteri Pendidikan dan Kebudayaan Republik Indonesia Nomor 24 Tahun 2016 Tentang Kompetensi Inti (KI) Dan Kompetensi Dasar (KD) Pelajaran dalam Kurikulum 2013 Pada Pendidikan Dasar dan Pendidikan Menengah. Jakarta: Badan Stan. 
[3]Prastowo, A. 2011. Panduan Kreatif Membuat Bahan Ajar Inovatif. Yogyakarta : Dipa Press.

[4]Buzan, T. 2008. Buku Pintar Mind Map. Jakarta : Gramedia Pustaka Utama.

[5]Siswono, T.E. 2005. Model Pembelajaran Matematika Berbasis Pengajuan dan Pemecahan Masalah untuk Meningkatkan Kemampuan Berpikir Kreatif. Surabaya: Surabaya: Unesa University Press.

[6]Ainurrohmah, A dan Mitarlis. 2019. Pengembangan Lembar Kerja Peserta Didik (LKPD) dengan Strategi Mind mapping untuk Meningkatkan Keterampilan Berpikir Kreatif pada Materi Koloid. s.l. : Unesa Journal of Chemical Education, 2019, Vols. 8; 1, 67-74.
[7]Qomariyah, N dan Mitarlis. 2017. Penerapan Pembelajaran Kooperatif Tipe TPS dengan strategi Mind mapping untuk Meningkatkan Keterampilan Berpikir Kreatif Siswa pada Materi Laju Reaksi. Surabaya : Surabaya : FMIPA-Unesa.

[8]Gredler, M.E. 2013. Learning and Instruction Teori dan Aplikasi. s.l.: Jakarta: Kencana.

[9]Ibda, Fatimah. 2015. Perkembangan Kognitif: Teori Jean Piaget. s.l. : Jurnal Pendidikan Kimia. Vol. .4; 1, 32-34.

[10]Riduwan. 2015. Skala Pengukuran Variabel-variabel Penelitian. s.l.: Bandung: Alfabeta, 2015. 